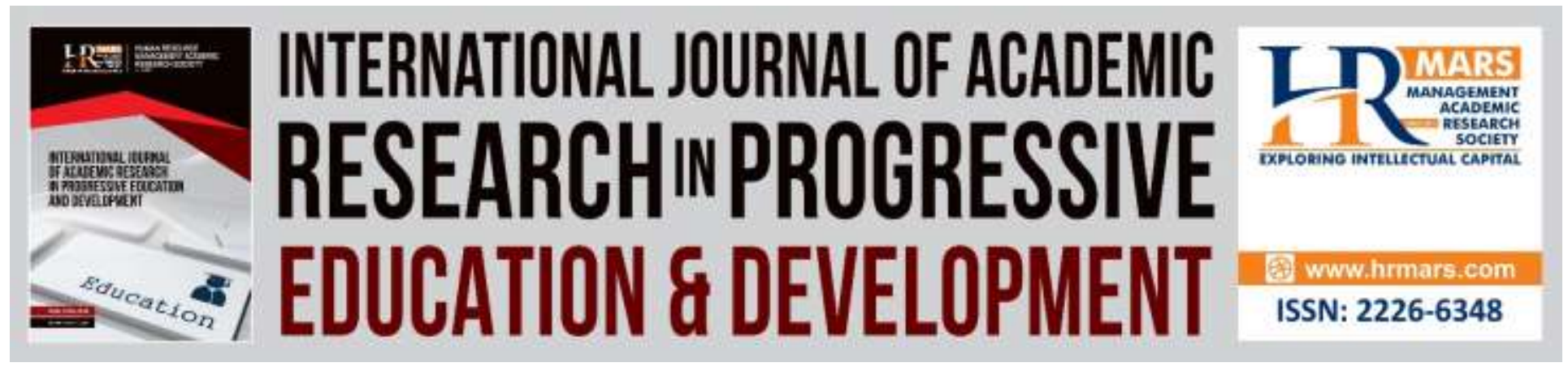

\title{
A Portrait of Acculturation in Postcolonial Writings: An Analysis of Aliyu Kamal's Silence and a Smile
}

Umar Saje, Mal. Inuwa Mahmud

To Link this Article: http://dx.doi.org/10.6007/IJARPED/v9-i2/7264

DOI:10.6007/IJARPED/v9-i2/7264

Received: 15 Jan 2020, Revised: 27 Feb 2020, Accepted: 11 Mar 2020

Published Online: 30 Mar 2020

In-Text Citation: (Saje \& Mahmud, 2020)

To Cite this Article: Saje, U., \& Mahmud, M. I. (2020). A Portrait of Acculturation in Postcolonial Writings: An Analysis of Aliyu Kamal's Silence and a Smile. International Journal of Academic Research in Progressive Education and Development, 9(2), 113-123.

Copyright: (C) 2020 The Author(s)

Published by Human Resource Management Academic Research Society (www.hrmars.com)

This article is published under the Creative Commons Attribution (CC BY 4.0) license. Anyone may reproduce, distribute, translate and create derivative works of this article (for both commercial and non-commercial purposes), subject to full attribution to the original publication and authors. The full terms of this license may be seen at: http://creativecommons.org/licences/by/4.0/legalcode

Vol. 9(2) 2020, Pg. 113 - 123

http://hrmars.com/index.php/pages/detail/IJARPED

JOURNAL HOMEPAGE

Full Terms \& Conditions of access and use can be found at http://hrmars.com/index.php/pages/detail/publication-ethics 


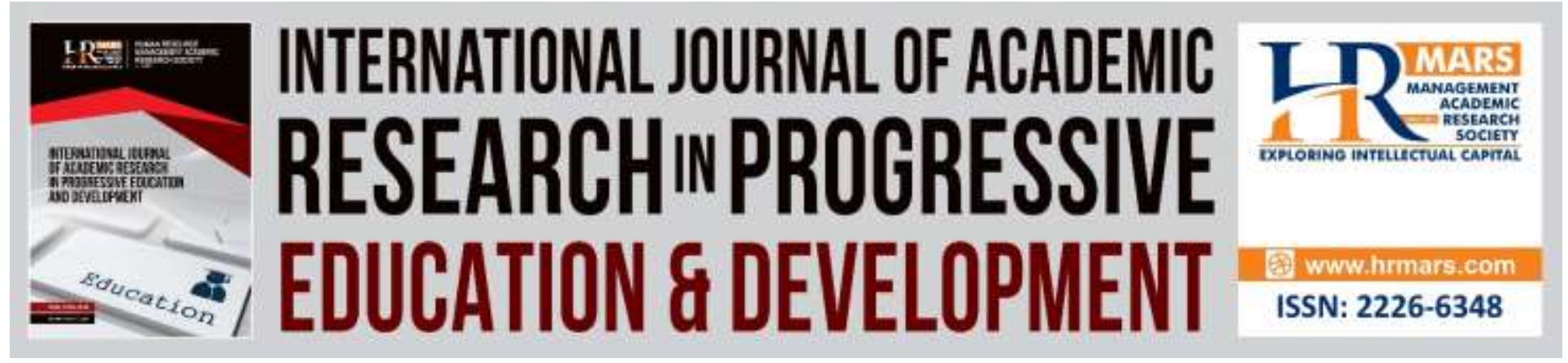

\title{
A Portrait of Acculturation in Postcolonial Writings: An Analysis of Aliyu Kamal's Silence and a Smile
}

\author{
Umar Saje ${ }^{1}$ (Ph. D.), Mal. Inuwa Mahmud ${ }^{2}$ \\ ${ }^{1}$ Department of Languages (English Unit), Sule Lamido University, Kafin-Hausa, Jigawa State, \\ Nigeria, ${ }^{2}$ Kano State College of Education and Preliminary Studies (Part-time) \\ Email: sajeumar@yahoo.com, Ibnmahmud00@gmail.com
}

\begin{abstract}
From time immemorial, literary writers via the three arms of literature have examined (and are still examining) the extent to which certain phenomena have permeated a social setting and their detrimental consequences on the corporate existence of the society or nation. Aliyu Kamal is one of such writers who discusses the religious aspirations and cultural values of the Hausa Muslim society of the northern Nigerian region in most of his works and how they have been affected by the onslaught of modernization. This paper examines the portrayal of the after-effects of foreign culture in a postcolonial Nigerian society, as treated in Kamal's Silence and a Smile (2005). He presents a society that faces an identity crisis in the process of cultural transformation emanating from intercultural contact. By the application of postcolonial theory as the theoretical framework, the paper pinpoints how the author, through the portraiture of some of his characters, depicts the influence of acculturation on northern Nigerian youth emphatically in terms of attire and the rejection of some cultural marital rites like giving toshi (gift of money) to a lady one courts and bringing lefe (trousseau) to the bribe's house before the marriage. The findings established the impact of acculturation as a major inclination and trend that portrays social reality to the detriment established traditional practices.
\end{abstract}

Keywords: Silence, Smile, Acculturation, Portraiture, Post-colonialism.

\section{Introduction}

Acculturation as a term has been described by various scholars from different scopes and perspectives. Hornby (2006:10) defines it "as the act of learning to live successfully in a different culture." The New Dictionary of Sociology explains it as a process whereby an individual or a group acquires the cultural characteristics of another through direct contact and interaction. Also, the Encyclopedia Britannica Volume 1 (1994:57) explained acculturation "as the process of change in artifacts, customs and beliefs that result from the contact of societies with different cultural traditions." In other words, acculturation is when groups of individuals, having different cultures, come into continuous first hand contact even though the original cultural patterns of 
either or both groups remain distinct (Kottak, 2005). Through acculturation, many Africans are made to keep aside their native cultural heritage and at the same time make use of a foreign culture, such as dressing, language, beliefs, customs and traditions, mostly unbefitting to their corporate social existence.

African writers like P'Bitek in Song of Lawino and Song of Ocol (1960), Armah in Beautyful Ones Are Not Yet Born (1968), Soyinka in Death and the King's Horseman (1975) and The Lion and The Jewel (1963), Achebe in No Longer At Ease (1964) and Yari in Climate of Corruption (1978) and Man of the Moment (1992), among others, have portrayed the impact of acculturation on Africans. Achebe, through the lips of Oberika, one of the male characters in Things Fall Apart (1958), harps against the influence of westernization among lgbo people, in particular, and Africans, in general. In a regrettable tone, Oberika avers:

The domination of African languages and cultures by imperialist Europe resulted in hybridizing the cultures and gave birth to the destabilization of African indigenous ways of life. Ngugi (2007:293), in his seminal paper, titled "The Language of African Literature", explains that culture is a product and a reflection of human beings communicating with one another in the very struggle to create wealth and control it. European culture was imposed on African culture through deceptive and forceful means. Against this background, this paper examines the effects of westernization on northern Nigerian youth as depicted in Kamal's Silence and a Smile- the novel under analysis.

\section{Aliyu Kamal: The Artist}

Aliyu Kamal, one of the prolific writers in English from the populous northern Nigerian region, comes from Kano, a predominantly Hausa Muslim community. He is currently a Professor of Applied Linguistics teaching in the Department of English and Literary Studies, Bayero University, Kano. Having published fourteen novels, a collection of short stories and an anthology of poetry in two decades, Kamal is now regarded as the leading male novelist in the world of northern Nigerian novel genre after the demise of Abubakar Gimba, "a giant oak of the North." Kamal's contribution to the literary world is enormous. He contributes in filling the literary vacuum in northern Nigeria to contest the claim that little is known about northern Nigerian writers writing in English. According to Tanko (2017:142):

Kamal's years in the ancient city of Kano and its environs afford him considerable experiences about the Hausa and Fulani cultures and challenges. Kano and its surrounding is a hub of the Hausa people, and predominantly feature as settings in many of Kamal's novels.

As a social critic, Kamal writes within the ambivalence of his society. He is particularly concerned with moral decadence and cultural conflicts at the individual and public levels. Umar (2012:251) describes Kamal as a writer who "unveils the cultural and religious values of the Muslim North." His novels like The Blaming Soul (2005) and Portrait of a Patron (2006), for instance, are significantly religious in their thematic treatments. They are based on moral truth because of their concern with the treatment of the major aspects of Muslims Life, cultural scope and religious precepts with particular reference to the Hausa social context. As Tanko (2017) further 
observes: North." Kamal's contribution to the literary world is enormous. He contributes in filling the literary vacuum in northern Nigeria to contest the claim that little is known about northern Nigerian writers writing in English. According to Tanko (2017:142):

Most of his writings are exploration and exposition of the Hausa culture, people, beliefs and land. Each of his nine novels has the word 'Hausa' attached to each of the titles: Hausaland (2003), Hausa Girl (2010) and Hausa Boy (2011).

Obviously, Kamal's novels engage the reader in a psychological, sociological and economic analysis of the goings-on in his society. His novels are full of moral lessons and guide to the right path. They are mainly on contemporary northern Nigeria. Kamal, as Umar (2012:41) argues:

Is a captivating writer with a remarkable eye for Hausa cultural situations, who notes down almost all the minutest details, especially those that matter in the light of the emerging global situation where the world is shrinking to a global village... Kamal's philosophy behind his choice of Hausa cultural practices and society as the setting of his novels aims to explore by tracing the contour of moral and religious crisis as manifested by the individuals, being products of multicultural settings in their attempt to prevail in the context of wider societal crisis.

Evidently, the general thrust of Kamal's novels revolves around the problems of the Nigerian society and Africa at large with a view to drawing attention to the measures to be taken for a better possible society. He tries to present his own view about how an ideal society would look like in an effort to offer his quota towards making his society an ideal one through bringing current social issues into the limelight. He always comes up with a new theme every now and then in any novel he writes. According to Muhammad (2017:287):

Writing is the medium through which writers express their feelings, thoughts and ideas. It is an avenue through which writers commit readers to the understanding of a particular issue or happenings in the society. Writing is therefore, an academic endeavour which not only requires intellectual energy but reveals to the readers who the writer is, may be his breadth of knowledge and his craftsmanship in choosing among thousand and one linguistic items to communicate or narrate a particular situation.

Corroborating Muhammad's observation, Sylvester (2016:29) rightly expresses that "Literature plays a powerful role in the socio-cultural practices of which the writer is rooted. It is the writer's responsibility to be awake to the happenings around him and serve as a cultural ambassador." 
INTERNATIONAL JOURNAL OF ACADEMIC RESEARCH IN PROGRESSIVE EDUCATION AND DEVELOPMENT

Vol. 9, No. 2, 2020, E-ISSN: 2226-6348 @ 2020 HRMARS

\section{Theoretical Framework}

Postcolonial theory is the approach used in analyzing the text under examination. It is a theory that deals with literature produced in countries that were once, or are still, colonies of other countries. Abrams (1999) defines postcolonial theory as "the critical analysis of the history, culture, literature, and modes of discourse that are specific to the former colonies of England, Spain, France and other European imperial powers." Dobie (2006:206) argues that interest in post-colonialism dates back to the fifties when Alfred Sauvy coined the term "Third World" to mean developing nations, such as those in Africa. They differ from what has come to be known as the First World countries in most of Europe and the United States, which are characterized by industrialization, democracy, relative affluence and similar cultural assumptions and beliefs.

The theory can be seen as an effort of re-affirming oneself either in terms of colour, group, nationality or individuality. It recognizes cultural, social, regional and national differences in experience and outlook and the unequal representation of the other as immoral, uncultured and uncivilized. Ashcroft et al (1989:11) posit that "Postcolonial literary theory emerged from the inability of European theory to deal adequately with the complexities and the varied cultural provenance of post colonial writings."

Consequently, the theory involves postulations on experiences of various kinds, such as migration, slavery, suppression, resistance, representation, race, gender, place, etc. Postcolonial Literature, therefore, resulted out of the interaction between Western culture and the complex of indigenous practices. Thus, the theory has been in existence for a long time before formal conceptualization and the specific name used to describe it as postcolonial theory. It is also described as a continuity process of resistance and reconstruction. As such, the theory is deployed to diagnose and describe the social context of Kamal's Silence and a Smile.

\section{The Novel: Silence and a Smile}

First published in 2005, Kamal's Silence and a Smile reflects the life of Ashiru Lawal (a young man of twenty-two), who studied Laboratory Technology and has completed National Youth Service Corps at Taraba State. He got employment with City College and thereafter proposes to Dija Garba, the sister of his bosom friend's wife but her Fulani family rejects him in favour of Zakiy (her cousin), whom she totally dislikes. On the day of her forced kinship marriage to Zakiy, she runs back to her mother's house immediately after the old women who accompanied her to his house left. She promised never to go back to his house. Zakiy has no option but to divorce her. She eventually marries Ashiru as a divorced virgin in spite of her uncle's threat. They live happily after the marriage. In this way, the author could be said to have made remarkable success in the book's title-Silence and a Smile. Against this background, Jaji (2015:100) writes, "In Silence and a Smile, both Ashiru and Dija could not conform to the custom of kinship marriage because they are all graduate members of an elite class and in spite of their efforts to conform to the social norms, they end up 'apart from' society. In terms of personal life style, they are different and apart from the rest of the community."

\section{Decadence in Silence and a Smile}


Kamal's Silence and a Smile portrays a certain level of moral decay in the Hausa Muslim community of Kano, the most populous state in northern Nigeria, as evident in the lives of the major characters, particularly the male. For instance, Alhaji Malle, Garbu and Sambo are depicted as corrupt, cheats and fraudulent. Other male characters like Ashiru, Hamidu, Zakiy and to some extent Isa Malle are insincere and deceitful. Through them, the author discusses and condemns moral vices like excessive smoking among youth, deception, indecent dressing, corruption and womanizing among a plethora of other social ills treated in the novel. According to Buba (2013:73):

Aliyu Kamal's novel Silence and a Smile has touched the lives of people in the society and when understood, a lot of lessons should be learnt by the society. This will enhance the growth and development. Clearly, the novel touched on issues of traditional marriage (kinship), greed, corruption and road safety.

From the very first page of the novel, the author depicts how westernization has entered deep into the fabric of northern Nigerian youth, especially in terms of dress. The portraiture of Ashiru Lawal, the protagonist of the novel, when he arrives back to Kano after the completion of National Youth Service Corps from Taraba state, is a clear justification of this instance. The way he dresses is considerably different from the usual Hausa dress code in the immediate past. A graphic picture of how he dresses is painted in the following lines:

His low haircut added to the picture, while his shirt, jeans and shoes completed it. He wore the shirt outside the trousers in the usual daytime fashion and his shirts sleeves with the dual folds (P.3).

The author here invites us to realize that some Islamic values, which are the foundation of Hausa cultural values, have been subverted and undermined by the new 'fashion' among youth. That is why when Ashiru reports at the City College where he got an appointment as lecturer, the Head of his Department takes him as someone who comes from southern Nigeria. He says to him, "It is your clothes which fooled me. People here generally prefer native attire" (P.47). This depicts the onslaught of modernization or colonialism in general on the people (especially youth like Ashiru) in the northern part of Nigeria, nay, Kano, a predominantly Hausa Muslim community. According to Fanon (1961:200):

Colonialism is a systematic negation of the other person and further determination to deny the other person all the attributes of humanity, colonialism forces the people it dominates to ask themselves the question constantly. In reality, who am I? 
Throughout the universe of the novel, Ashiru condemns Hausa culture, especially buying the trousseau, when it comes to marriage issues. He accuses Hausa women who participate greatly in it but his step-mother, Larai, reminds him that "You can't go around the culture if you really want to marry. The reason is that, it has been inextricably tied up with religious practice" (P.74). Also, Ashiru, like Umar Faruq (the protagonist of Kamal's Fire in my Backyard, 2004), regards the Hausa culture of kneeling down to greet one's elders as abhorrent and outdated. His aversion of such an archaic traditional way of greeting is clearly pointed out in the narrative:

Ashiru lacked such deep knowledge, but for the moment he took a deep dislike for such cultural practices as bowing before the elderly, showing deference in approaching them by removing his shoes, as well as elaborated wedding rituals, which didn't conform to what he considered proper conduct (P.130).

At this juncture, it is important to stress that Ashiru and other "been-tos" like him should acknowledge that the culture of a people is their potent identity; the demise of the culture of a people is by extension the demise of the people themselves. When people lose their possessions, particularly culture, they end up losing their original identity. It is, therefore, important for one to uphold the good aspects his culture and glorify it than throw it way and uphold one that is alien. A person that throws away his culture and prioritizes that of others because of its beauty is a subject of ridicule in life.

Kamal also uses his portraiture to make a biting critical comment of the negative behaviour of some youth in his contemporary Hausa society. It is obvious in the novel that Ashiru finds it appropriate to smoke in front of anyone he likes due to the influence of the modern polluted world on him. He tries to light a cigarette at his sister's house but she cautions him that her husband doesn't like it. She says to him, "Don't smoke here; Alhaji disapproves of it" (P.18). In Hausa society, a smoker is seen as an immoral person no matter his age. This doesn't concern Ashiru in as much as he gets the desired relaxation from it. That is why he takes courage to flashback on his girl-friend, Dija, and the altercation between him and Ahmad (his elder brother) when he caught him smoking. He narrates to her:

He caught me smoking at home. Father had gone to work. Ahmad said that he didn't smoke: Father didn't smoke: why should I, the eldest sibling living in the house, smoke? He asked me not to go to his house ever again if I chose to continue smoking. And because I didn't want to give up I stopped going there. He gave up in the end by calling me to go on an errand for him (P.34).

This bad habit of Ashiru's is copied by Hamidu as Ahmad (their elder brother) has feared initially. That is why he always protects Hamidu whenever he is accused of committing any offence. Certainly, Hamidu may have learnt some of his bad habits from Ashiru. In fact, the two close 
brothers virtually share the same personality trait. Both are smokers, womanizers and deceivers. The only thing that probably makes them different is education. Whereas Ashiru has a passion for it (we meet him as an employed graduate from the very beginning of the novel) and advises Hamidu, saying to him, "I am serious. Father isn't getting younger by the day. If you care about his blood pressure, you will listen to me" (P. 52) because he wants him to go back to school and continue his studies, Hamidu, on the other hand, has total hatred and abhorrence for it. He prefers spending the whole day smoking to attending any school. He says to Ashiru, "I remember you saying one doesn't need a degree to succeed in life" (P. 53). Ashiru keeps pretending to his father that he is a virtuous and an upright person while in reality he isn't because whenever Hamidu is caught doing something bad, he will blatantly lie to their father in order to set Hamidu free of any punishment. Being a skillful liar, Ashiru keeps betraying his father, such that Malam Lawal, up to the end of the novel, never realizes that he is the chief agent of Hamidu's waywardness. In order to save Hamidu, Ashiru quickly takes the blame because he doesn't want him to disclose his secret (that is, he learnt it from him). His statement that it is 'his fault' surprises their father and puts him in a state of confusion. Malam Lawal almost realizes the truth, as he says to Ashiru that he doesn't understand what he means. But being an accomplished liar, Ashiru instantly confesses that he gives pocket money to Hamidu. Also, when Ashiru's nameless sister, who sells dumplings, flashbacks to him that Hamidu was dismissed from his job because of embezzlement, instead of rebuking his action, he praises and protects him. He responds by saying to her that he, too, can do the same if he is paid for less than what his labour is worth. That is why when Ashiru says to Isa that his first assignment is Hamidu, Isa frankly says to him, "Let the doctor cure himself before attending to other patients"(p.28).

Earlier in the story, Ashiru and Isa Malle engage in fleeting love affairs with two hawkers, Kande and Shatu. Isa congratulates Ashiru to be in Taraba when Shatu (his girlfriend) was discovered pregnant. Ashiru also deceived Agnes (his other girl-friend) whom he met at Taraba during his NYSC. Isa says to him, "Imagine Agnes coming to your house and asking about you" (P.89). He answers him that, "Father would have banished me forever". That is why they parted without him letting her know his real address. Looking at these instances, we should not be surprised if any of Ashiru's brothers, particularly the wayward Hamidu, is caught committing adultery.

Hamidu is a younger version of Sule in Yari's Climate of Corruption (1984) and Sadiq in Kamal's Fire in My Backyard (2004). His waywardness resembles that of Sule, Li's brother, and, in terms of smoking, he is a carbon copy of Habu Adam (Li's husband) and Garba (Faku's husband) in Alkali's The Stillborn (1984). Hamidu's unscrupulousness becomes lucid, as he always short changes his mother on every errand to satisfy his own idle leisurely needs. Malam Lawal has stopped giving him money in order to distance him from smoking. When Ashiru asks him how he gets money to smoke since he is jobless, he says to him, "I buy less than whatever mother asks me to buy for her. Ahmad also used to disobey that cursed mother of his and give me a few coins" (P.52). He smokes in the latrine to avoid being caught by his father. The author, in chapter five of the novel, paints a cinematic picture of the two close brothers smoking together. Ashiru says to Hamidu, "I just forget to buy a packet at the college", but they share the one available fifty-fifty and laugh for the delicacy of it (P. 53). It is clear that Hamidu is encouraged by Ashiru to do whatever he likes (to smoke unstoppably). To encourage him most to smoke, Ashiru says to him, "I have forgotten what cheap unfiltered cigarettes taste like. Ever since our primary school days 
when we learnt how to smoke." Also, it could be well corroborated through the consideration of the dialogue below of how close the two brothers are. Ashiru says to Hamidu:

"Your eyes have begun to redden, Hamidu."I have my dark goggle,"

said the letter, as they walked out of the house.

"But it easily gives you away as an addict".

"I mind my own business".

"I like you for that. As father used to say, never dabble in what doesn't concern you" (PP.55-6).

However, towards the end of the narrative, Ashiru confirms that he is reformed to an upright person and weds Dija Garba but not Hamidu. He remains a bachelor and makes no attempt to find himself a partner throughout the text. He metaphorically marries a cigarette. He usually lies fully covered in bed and smokes. To crown it all, Hamidu is completely unrepentant and incorrigible because up to the end of the novel, his father is still afraid of involving him in any of his businesses. As Malam Lawal says to Ahmad and Ashiru, "Neither Hamidu nor I can continue with the business. I can't do so because of my age and Hamidu will follow in the way of Sambo" (P.217).

\section{Female Characters and the Influence of Modernity in Silence and a Smile}

The influence of modernity in contemporary northern Nigerian region does not affect men alone but also affects women as evident in Silence and a Smile. The teenage female characters in the novel are portrayed in a modern society where girls are allowed to pursue education without encumbrance or male preference. Dija, Husna and Jummai, for instance, go up to the university level. They all drive cars, which is not just a sign of modernization but a symbol of upward mobility. Dija drives a Honda Concerto, Husna a Toyota Starlet and Jummai her father's Mercedes. Also, they have all married husbands of their choice (Dija marries Ashiru, Husna Mansur and Jummai Dauda). Unlike before in Hausa society where, in most cases, young ladies were often denied such a right. Rather, they were persuaded and sometimes blackmailed by their parents into forced kinship marriages with husbands they abhorred.

The western education that Dija acquires enables her to fight against the choice of a husband made for her by her family unlike her sister Zohra, who due to lack of education, submissively accepted Isa (her family choice). Dija, on the other hand, out-rightly rejects Zakiy (her cousin). This action of her annoys her mother and Uncle Malle (her guardian). Her mother says to her, "Do you know that nobody in this family has ever done this before?" and her guardian adds that, "It could be the times; children no longer listen to their elders" (p.208). Her uncle promises never to buy her a single stick of furniture and foodstuff if she marries Ashiru. Being modernized, Dija, after her uncle left, responds to her mother: "I prefer to lead a life of penury with the man I love than the life of bliss with the one I will never love" (p.210). In this way, Dija, as Mahmud (2016:70) puts it, "adamantly denies her family's practice of forced kinship marriage. She chooses to marry Ashiru Lawal who is poorer than Zakiy, her cousin. Her choice of Ashiru as her husband suggests her independence of mind and voice." Not only that, the three friends promised to be independent even after marriage. Dija says to Jummai on their way to Husna's house, "I won't be entirely dependent on him. Once I graduated, I'll start working. I'll institute my own measure of 
control by contributing to the family budget"(p.169). Jummai responded by encouraging her to maintain her opinion on the issue. She says, "Wives now work. They have started to pick up the reins of control that men have denied them for ages"(p.170).

Another clear instance of the effects of westernization on Hausa youth is graphically depicted in the narrative. During Husna's wedding party, "The couple, smiling and holding hands with the groom shaking hands with all men around and the bride smiling along-"(p.163). That is against Hausa tradition. Also, by using Hafsa as his mouth-piece, the author criticizes the behavior of some women towards their parents and husbands. In a shrill voice, Hafsa criticizes her daughters:

What has come over to all you children? The older one calls her husband by name. And the younger one is trying to reject hers on the very day their marital knot is tied. Who could have ever thought that young girls like you- only children- would behave like this? No wonder though; it's nothing but the times causing all this rashness to happen (p.206-7).

The above reference pinpoints one of the influences of modernization in contemporary Hausa Society. Also, some Hausa women because of westernization prefer male to female tailors. As Isa says to Ashiru, "Let me inform you, almost all women patronize male tailors nowadays"(p.32). Still on the novel under examination, Saje (2019:190), examines the influence of modernity on the corporate Hausa social system and explains how the long standing Hausa cultural norms and values have been adversely affected with attendant repercussions on the society as a result of contact with the alien values. The scholar equally examines Kamal's concern with the collapse of these values vis-à-vis Hausa societal development.

\section{Conclusion}

On the whole, Aliyu Kamal's Silence and a Smile is a quintessential 'regional novel' that treats some of the most pressing social ills in the modern Hausa society of northern Nigeria. It discusses not only how Hausa traditional culture, which is highly moralistic and religious, contrasts sharply with the Hausa society of today but reveals the plight of the individual, who attempts to locate his or her individualism in a changing social order. On a final note, it is apt to make it obvious that the author's attempt to communicate on his society's moral decay using a foreign language (English) is in itself one of the effects or rather an indication of the consequences of acculturation.

\section{References}

Abrams, M. H. (1999). A Glossary of Literary Terms ( $7^{\text {th }}$ Edition). USA: Heinle and Heinle Achebe, C. (1958), Things fall Apart, London: Heinemann.

Alkali, Z. (1984), The Stillborn, Lagos: Longman.

Ashcroft, B., Griffiths, G., and Tiffin, H. (1989). The Empire writes back. London: Routledge.

Buba, A. M. (2013) "The Writer and Socio-cultural Burden: A Study of Abubakar Gimba's Sacred Apple and Aliyu Kamals' Silence and a Smile." Unpublished M.A Dissertation Submitted to the Department of English and Literary Studies, Bayero University, Kano. 
INTERNATIONAL JOURNAL OF ACADEMIC RESEARCH IN PROGRESSIVE EDUCATION AND

DEVELOPMENT

Vol. 9, No. 2, 2020, E-ISSN: 2226-6348 @ 2020 HRMARS

Dobie, A. (2006). Theory into Practice: An Introduction to Literary Criticism. New York: Wordworth Fanon, F. (1961). The Wretched of the Earth. UK: Penguin.

Hornby, A. S. (2006), Oxford Advanced Learner's Dictionary of Current English, First impression, New York.

Jaji, S. A. (2015). "Some Issues on the Novel in Northern Nigeria" in S. B. Ahmad, S. A. Aliyu and A. Murtala (eds), Literature in Northern Nigeria: From Foundations to Contemporary Challenges. Beyero University, Kano. Pp.81-105.

Kamal, A. (2005). Silence and a Smile. Zaria: Ahmadu Bello University Press.

Kamal, A. (2005). The Blaming Soul. Zaria: Ahmadu Bello University Press.

Kamal, A. (2006). Portrait of a Patron. Zaria: Ahmadu Bello University Press.

Kamal, A. (2004). Fire in My Backyard. Zaria: Ahmadu Bello University Press.

Kottak, C. P. (2005) Windows on Humanity. New York: Mc Graw Hill.

Mahmud, I. (2016) "Representation of Women in Nigerian Literature: A Study of Aliyu Kamal's Silence and a Smile and Hausa Girl" unpublished M. A. Dissertation submitted to the Department of English and Literary Studies. Bayero University, Kano.

Mitchel, G. D. (ed) (1979) A New Dictionary of Sociology. London: Rottledge and Kegan Paul.

Muhammad, A. (2017) "Style as the Man: A Fact or a Fiction? Evidence from Aliyu Kamal's Hausa Girl", in Liman, A. (ed) Work in Progress. Zaria: Ahmadu Bello University Press Limited. No.16 Pp.286-299.

Saje, U. (2019). "A Thematic and Stylistic Analysis of Aliyu Kamal's novel Silence and a Smile" in B. Zulyadaini (Ed.), Yobe Journal of Language, Literature and Culture (Yojallac). Damaturu: Yobe State University, Vol. 7. Pp.188-197.

Sylvester, M.V. (2016) "Self-criticism: Abubakar Gimba and his Transformative Ideals of Nationhood", in Egya, S.E (ed) Lapai Research in Humanities. Vol.3, no.2, pp.25-43.

Tanko, H. A. (2017) "The True Image of Northern Nigeria in Kamal's Hausaland", in Abdulraheem, H.I, Aliyu, S.B and Akano, B.K (eds) Literature, Integration and Harmony in Northern Nigeria. Kwara State University Press, pp. 141-150.

Umar, B. (2012) "The Influence and Intrusion of alien cultures in Hausa society of northern Nigeria: Analysis of Kamal's The Blaming Soul", in Umar, B. (ed) The Writer: Journal of Language, Literature and Teaching Methodology, Sa'adatu Rimi College of Education, Kumbotso, Kano. Vol.2 pp.41-50.

Umar, N. A. (2012) "Cultural and Religious Consternation in Northern Nigerian Literature: Reading Aliyu Kamal's Hausa Girl", in Sambo, B. (ed) Katsina Journal of Linguistics and Literary Studies, vol.1 pp.249-262.

Wa Thiong'o, N. (2007). "The Language of African Literature" in O. Tajumola and A. Singapora (eds), African Literature: An Anthology of Criticism and Theory. Blackwell Publishing Ltd.

Yari, L. (1984IU). Climate of Corruption. Enugu: Fourth Dimension. 